Jurnal KONTEKSTUAL

Volume 01, No. 1, Agustus 2019, pp. 39-44

\title{
ANALISIS MINAT BELAJAR SISWA LAKI-LAKI KELAS V DALAM PEMBELAJARAN SENI TARI (STUDI KASUS DI SDIT NURUL HIDAYAH BREBES)
}

\author{
Devi Nisa Ashobah ${ }^{1}$, Rizki Umi Nurbaeti*2 ${ }^{2}$, Moh. Toharudin ${ }^{3}$ \\ 1,2,3Prodi Pendidikan Guru Sekolah Dasar, Fakultas Keguruan dan Ilmu Pendidikan, Universitas \\ Muhadi Setiabudi Brebes, Indonesia \\ e-mail: riskiuminurbaeti@gmail.com
}

\begin{abstract}
Abstrak
Penelitian ini bertujuan untuk mendeskripsikan faktor yang mempengaruhi minat belajar siswa laki-laki dalam pembelajaran seni tari dan problematika dalam pembelajaran seni tari. Penelitian ini adalah penelitian kualitatif dengan pendekatan deskriptif. Informan dalam penelitian ini yaitu kepala sekolah, guru kelas V, guru ekstrakurikuler seni tari, siswa laki-laki kelas $V$ dan wali siswa kelas $V$. Teknik pengumpulan data menggunakan observasi, wawancara dan dokumentasi. Keabsahan data dilakukan dengan triangulasi teknik dan sumber. Teknik analisis data yang digunakan adalah reduksi data, penyajian data dan penarikan kesimpulan. Hasil penelitian ini adalah (1) faktor internal yang mempengaruhi adalah pada minat dan tingkat kelelahan rohani yang dialami oleh siswa sedangkan dalam faktor eksternal yang mempengaruhi adalah keadaan gedung, relasi guru dan siswa serta perhatian orang tua. Dalam pembelajaran seni tari juga terdapat (2) Problematika dalam pembelajaran seni tari meliputi kendala yang hadapi oleh guru kelas dan siswa bahwa guru tidak memilki kompetensi dalam seni tari, guru hanya memberi tahu gerakan tari lewat gambar tanpa mempraktekkan hal tersebut menjadikan kendala bagi siswa, siswa merasa kesulitan dalam mempraktekkan gerakan seni tari dan membuat siswa malas untuk belajar seni tari dan membuat siswa laki-laki kurang minat pada saat pembelajran seni tari berlangsung.
\end{abstract}

Kata kunci: Minat, Pembelajaran Seni Tari.

\begin{abstract}
This study aims to describe the factors that affect the learning interests of male students in learning dance and problems in learning dance. This research is a qualitative research with a descriptive approach. The informants in this study were the school principal, class $V$ teacher, dance extracurricular teacher, class $V$ male student and guardian of class $V$ student. Data collection techniques used observation, interviews and documentation. The validity of the data is done by triangulation of techniques and sources. Data analysis techniques used are data reduction, data presentation and conclusion drawing. The results of this study are (1) internal factors that influence are the interest and level of spiritual fatigue experienced by students while in external factors that influence is the state of the building, the relationship of teachers and students as well as parents' attention. In learning dance there are also (2) Problems in learning dance include the obstacles faced by class teachers and students that the teacher does not have competence in dance, the teacher only tells dance movements through pictures without practicing it makes obstacles for students, students feel difficulties in practicing dance movements and make students lazy to learn dance and make male students less interested when learning dance takes place.
\end{abstract}

Keywords: Interest, Dance Art Learning

Submitted: 2019, Accepted: 2019, Published: Agustus 2019

ISSN: xxxx-Xxxxx (online), Website: http://jurnal.umus.ac.id/index.php/kontekstual 
Jurnal KONTEKSTUAL

Volume 01, No. 1, Agustus 2019, pp. 39-44

\section{PENDAHULUAN}

Pembelajaran adalah suatu proses saling mempengaruhi antara guru dan siswa dalam kegiatan belajar mengajar. Pembelajaran dikatakan berhasil dan berkualitas apabila sebagian besar peserta didik terlibat secara aktif, baik fisik, mental maupun sosial dalam proses pembelajaran. Berdasarkan hal tersebut diatas, upaya guru dalam mengembangkan keaktifan belajar siswa sangatlah penting, sebab keaktifan belajar siswa menjadi penentu bagi keberhasilan pembelajaran yang dilaksanakan. Seorang guru dalam kegiatan belajar mengajar tidak hanya dituntut untuk memiliki kemampuan dalam pengalaman teoretis tapi juga harus memiliki kemampuan praktis. Kedua hal ini sangat penting karena seorang guru dalam pembelajaran bukanlah sekedar menyampaikan materi semata tetapi juga harus berupaya agar mata pelajaran yang sedang disampaikan menjadi kegiatan pembelajaran yang menyenangkan dan mudah dipahami bagi siswa.

Pembelajaran pada hakikatnya adalah suatu proses, yaitu proses mengatur, mengorganisasi lingkungan yang ada di sekitar peserta didik sehingga dapat menumbuhkan dan mendorong peserta didik melakukan proses belajar[1].

Pendidikan SBDP (Seni Budaya dan Prakarya) merupakan mata pelajaran produktif, sehingga sangat penting adanya upaya perubahan dan peningkatan dalam proses pembelajaran menciptakan sebuah karya. Hal ini pada akhirnya akan memberikan hasil dan kreativitas yang baik sehingga pembelajaran semakin meningkat. SBDP sebagai mata pelajaran di sekolah seharusnya dapat dirasakan sangat penting keberadaannya bagi siswa, karena siswa akan lebih mencintai keragaman budaya lokal dan global sebagai pembentukan sikap menghargai, demokratis, beradab, dan hidup rukun dalam masyarakat dan budaya yang majemuk.

Kata seni tari, yang terlintas dalam benak adalah gerak, kerena gerak merupakan media pokok dalam tari yang berfungsi untuk mengomunikasikan sesuatu pada penikmatnya/penonton[2]. Namun demikian tidak semua gerak dapat di katakan dengan tari, karena gerak itu tidak terlepas dari aktifitas kehidupan keseharian manusia yang bisa diolah sehingga menjadi gerak tarian. Artinya gerakan keseharian dapat di jadikan sumber gerak tari melalui pengelolahan sesuai dengan kebutuhan sebuah tari.

SDIT Nurul Hidayah Khususnya Siswa laki-laki Sekolah dasar menganggap bahwa seni tari itu merupakan seni pertunjukan untuk tujuan menghibur dan guru juga menganggap bahwa pembelajaran seni itu tidak harus selalu dilaksanakan di sekolah. pada saat proses pembelajaran berlangsung banyak siswa laki-laki yang kurang mampu menguasai materi yang disampaikan oleh guru baik praktik maupun teori. Banyak siswa yang mengeluh karena pembelajaran seni tari cukup sulit untuk di pelajari dan di hafalkan. Dan Selain itu siswa cenderung tertarik pada mata pelajaran yang mereka anggap sesuai dengan kebutuhan mereka, sesuai jenis kelamin, mudah dan menghasilkan nilai yang baik. Dalam pembelajaran seni tari, siswa laki-laki cenderung tidak berminat dibandingkan dengan siswa perempuan. Dilihat dari prestasi belajar siswa laki - laki dan siswa perempuan dalam pembelajaran seni tari berbeda.

Berdasarkan latar belakang yang telah di uraikan maka dapat dirumuskan masalah sebgai berikut (1) Apa sajakah faktor-faktor yang mempengaruhi minat belajar siswa laki-laki dalam 
pembelajaran seni tari ? (2) Bagaimana problematika dalam pembelajaran seni tari ?

Tujuan di adakannya penelitian ini adalah (1) Untuk mendeskripsikan faktor faktor yang mempengaruhi minat belajar siswa kelas $\mathrm{V}$ dalam pembelajaran seni tari di SDIT Nurul Hidayah Brebes. (2) Untuk mendeskripsikan problematika dalam pembelajaran seni tari siswa kelas $\mathrm{V}$ di SDIT Nurul Hidayah Brebes.

\section{KAJIAN TEORI \\ Definisi Minat}

$\begin{array}{ccr}\text { Minat } & \text { (interest) } & \text { adalah } \\ \text { kecenderungan } & \text { untuk } & \text { selalu }\end{array}$
memperhatikan dan mengingat sesuatu secara terus menerus[3]. Minat ini erat kaitannya dengan perasaan terutama perasaan senang, karena itu dapat dikatakan minat itu terjadi karena sikap senang kepada sesuatu. Pendapat lain berpendapat bahwa minat adalah suatu rasa lebih suka dan rasa keterikatan pada suatu hal atau aktivitas, tanpa ada yang menyuruh[4]. Minat pada dasarnya adalah penerimaan akan suatu hubungan antara diri sendiri dengan sesuatu di luar diri. Semakin kuat atau dekat hubungan tersebut, semakin besar minat. Minat adalah kecendurungan yang tetap untuk memperhatikan dan mengenang beberapa kegiatan[4].

\section{Belajar dan Pembelajaran}

Belajar (learning) sering kali juga didefinisikan sebagai "perubahan yang secara relatif berlangsung lama pada masa berikutnya yang diperoleh kemudian dari pengalamanpengalaman".

Belajar sebagai proses perubahan perilaku berkat pengalaman dan latihan. Artinya, tujuan kegiatan adalah perubahan tingkah laku, baik yang menyangkut pengetahuan, keterampilan maupun sikap; bahkan meliputi segenap aspek organisme atau pribadi[5].

Pembelajaran juga dikatakan sebagai proses memberikan bimbingan atau bantuan kepada peserta didik dalam melakukan proses belajar. Peran dari guru sebagai pembimbing bertolak dari banyaknya peserta didik yang bermasalah. Dalam belajar tentunya banyak perbedaan, seperti adanya peserta didik yang mampu mencerna materi pelajaran, ada pula peserta didik yang lambah dalam mencerna materi pelajaran. Kedua perbedaan inilah yang menyebabkan guru mampu mengatur strategi dalam pembelajaran yang sesuai dengan keadaan setiap peserta didik.

Faktor -Faktor yang mempengaruhi belajar banyak jenisnya, tetapi dapat digolongkan menjadi dua golongan saja, yaitu faktor internal dan faktor eksternal, faktor internal adalah faktor yang ada di dalam diri individu yang sedang belajar, sedangkan faktor eksternal adalah faktor yang ada di luar individu[5]. Faktor-faktor internal di dalam membicarakan faktor internal ini akan di bahas menjadi tiga faktor yaitu : faktor jasmaniah, faktor psikologi dan faktor kelelahan. Faktor-Faktor Eksternal Faktor eksternal yang berpengaruh terhadap belajar,dapatlah dikelompokan menjadi 3 faktor, yaitu: faktor keluarga, faktor sekolah, faktor masyarakat.

Dari pendapat beberapa ahli diatas peneliti menyimpulkan bahwa masalah-masalah tentang minat belajar siswa laki-laki dalam pembelajaran seni tari secara garis besar dapat diklarifikasikan menjadi dua yaitu dengan adanya faktor internal dan faktor eksternal dan mengenai kendala-kendala dan upaya yang akan dilakukan guru terhadap; siswa.

\section{Pembelajaran Seni Tari}


Yang dimaksud dengan pembelajaran adalah suatu organisasi yang tersusun meliputi unsur-unsur manusiawi, material, fasilitas, perlengkapan dan prosedur yang saling mempengaruhi mencapai tujuan pembelajaran, selain itu pembelajaran bersumber dan berbudaya dapat salah satu komponennya adalah tari[6]. Seni secara umum dan seni tari secara khusus dikenal sebagai rasa keindahan umum, rasa keharusan khususnya, yang melengkapi kesejahteraan hidup. Pembelajaran seni tari di SD bersifat edukatif dalam membantu perkembangan jiwa siswa SD. Dengan demikian, konsep pembelajaran seni tari adalah sebagai sarana atau media pendidikan. Hal ini merupakan konsep pendidikan yang paling sesuai dengan siswa SD dan selaras dengan pendapat bahwa kebudayaan itu bersifat non material dan bersifat abstrak ada dalam jiwa dan kepribadian manusia.

\section{METODE PENELITIAN}

Lokasi penelitian di SDIT Nurul Hidayah Brebes. Dalam penelitian ini Peneliti menggunakan penelitian kualitatif dengan menggunakan metode deskriptif dengan jenis penelitian studi kasus karena menyajikan data dalam bentuk kata-kata.

Fokus penelitian ini adalah Faktor-faktor yang mempengaruhi minat belajar siswa laki-laki dalam pembelajarn seni tari. dan problematika dalam pembelajaran seni tari. Penelitian menggunakan informan siswa laki-laki kelas V, kepala sekolah, guru kelas, guru ekstrakurikuler seni tari, Wali siswa lakilaki.

Sumber data penelitian ini yaitu 23 informan 10 informan siswa laki-laki (sumber data primer) 10 informan wali siswa, 3 informan pihak sekolah (sumber data sekunder)
Teknik pengumpulan data yang digunakan dalam penelitian ini adalah Observasi, wawancara, dan dokumentasi.

Keabsahan data yang diperoleh dilapangan perlu diuji keabsahannya. Keabsahan data untuk mendapatkan data bisa menggunakan triangulasi sumber, waktu dan teknik. Triangulasi yang digunakan dalam penelitian ini menggunakan triangulasi teknik dan triangulasi sumber[7].

Tiangulasi adalah teknik pemeriksaan keabsahan data yang memanfaatkan sesuatu yang lain dalam membandingkan hasil wawancara terhadap objek penelitian[8]. Dalam penelitian kualitatif, data diperoleh dari berbagai sumber, dengan menggunakan teknik pengumpulan data yang bermacam-macam (triangulasi) dan dilakukan secara terus menerus sampai datanya jenuh[8]. Teknis analisis data yang digunakan pada penelitian ini adalah teknik penelitian deskriptif.

\section{HASIL DAN PEMBAHASAN}

Berdasarkan data temuan dari wawancara mendalam yang dilakukan oleh peneliti kepada Informan tentang minat belajar siswa laki-laki kelas $\mathrm{V}$ dalam pembelajaran seni tari di SDIT Nurul Hidayah Brebes. yang didasarkan pada rumusan masalah dan indikator dalam penelitian dengan metode observasi, wawancara dan dokumentasi, didapatkan data dan jawaban yang sinkron antara satu informan dengan informan yang lain seperti minat belajar siswa laki-laki kelas $\mathrm{V}$ dalam pembelajaran seni tari di SDIT Nurul Hidayah Brebes.yang telah dipaparkan oleh Informan dalam wawancara dan didukung oleh dokumen. Bahwa dari siswa laki-laki tidak memiliki minat belajar terhadap pembelajaran seni tari maupun ekstrakurikuler seni tari. 
Berdasarkan minat belajar siswa laki-laki dalam pembelajaran seni tari yang telah dipaparkan diatas, peneliti menyimpulkan bahwa adanya 1) Faktorfaktor yang mempengaruhi minat siswa laki-laki dalam pembelajaran seni tari dan dapat di temui juga 2) Problematika dalam pembelajaran seni tari.faktor yang mempengaruhi minat belajar ada 2 yaitu faktor internal dan faktor internal didukung oleh pernyataan dari Slameto (2015) bahwa faktor internal dan faktor eksternal sangat mempengaruhi dalam belajar. dalam penelitian ini faktor internal meliputi minat dan kelelahan rohani sedangkan faktor eksternal meliputi keadaan gedung, relasi guru dan siswa serta perhatian orang tua.

Selain faktor-faktor tersebut ada problematika maupun kendala-kendala dalam pembelajaran seni tari guru kelas berkendala dalam gerakan seni tari, karena guru kelas tidak memiliki kompetensi dalam seni tari. karena hal tersebut siswa beranggapan sulit untuk belajar seni tari dan menimbulkan sukar untuk belajar seni tari selain itu guru ekstrakurikuler seni tari tidak memilki wewenang untuk memotivasi siswa dalam pembelajaran seni tari. jari karena hal tersebut guru ekstrakurikuler seni tari berkendala pada memotivasi siswa dalam pembelajaran seni tari.

Faktor-faktor dan problematika ini lah yang sangat mempengaruhi minat belajar siswa dalam pembelajaran seni tari siswa laki-laki kelas V di SDIT Nurul Hidayah Brebes. dalam hal tersebut Guru sudah berupaya agar siswa lebih berminat dengan seni tari dari pendekatan personal, perhatian khusus hingga reward. Dan pihak sekolah juga berharap agar minat siswa laki-laki bisa lebih baik agar memiliki kreatifitas dan prestasi.

\section{SIMPULAN}

Berdasarkan hasil penelitian dan pembahasan dapat disimpulkan bahwa kurangnya minat siswa laki-laki kelas $\mathrm{V}$ dalam pembelajaran seni tari di SDIT Nurul Hidayah Brebes dikarenakan ada beberapa faktor dan problematika sebagai berikut. Faktor-faktor yang mempengaruhi minat siswa laki-laki kelas V dalam pembelajaran seni tari. Faktor Internal yang dapat mempengaruhi minat siswa laki-laki kelas V dalam pembelajaran seni tari yaitu mengacu pada minat dan kelelahan rohani. Faktor Eksternal yang meliputi pada keadaan gedung, keadaan relasi guru dan siswa dan dalam perhatian orang tua. Selain itu problematika dalam pembelajaran seni tari. Kendala yang di hadapi guru kelas adalah pada saat praktek gerakan tari karena guru kelas tidak mengusai gerakan tari. guru ekstrakurikuler seni tari berkendala pada cara memotivasi siswa pada saat ekstrakurikuler berlangsung. dan bagi siswa sendiri adalah pada gerakan tarian yang sangat sulit untuk di hafal dan pemikiran siswa yang beranggapan bahwa seni tari adalah khusus untuk perempuan.

\section{REFERENCES}

[1] Pane, Aprida, 2017, Belajar dan Pembelajaran. Padang: IAIN https://scholar.google.com/scholar ?hl=en\&as sdt $=0 \% 2 \mathrm{C} 5 \& \mathrm{q}=\mathrm{JUR}$ NAL+BELAJAR+DAN+PEMBE LAJARAN+APRIDA+PANE\&bt

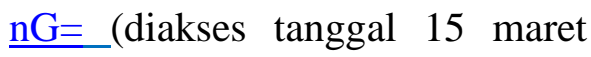
2019)

[2] Astuti, Fuji., 2016 Pengetahuan dan Teknik Menata Tari untuk Anak Usia Dini. Jakarta : Kencana

[3] Rohim, Abdul. Pengaruh Minat Belajar Terhadap Prestasi Belajar Siswa pada Bidang Studi PAI. 
Jurnal KONTEKSTUAL

Volume 01, No. 1, Agustus 2019, pp. 39-44

Jakarta : UIN Syarif

Hidayatuallah.

[4] Slameto,. 2015. Belajar dan Faktor-faktor yang Mempengaruhinya. Jakarta : Bineka Cipta.

[5] Irine, shita putrid dewi. 2013. Faktor-faktor yang mempengaruhi minat siswa dalam pembelajaran seni tari di SDN Randusari Kota Gede Yogyakarta : UNY.

[6] Zona, Iriyani. 2015. Peningkatan Mutu Pemebelajaran Seni Tari Di Sekolah Dasar Padang: Universitas Negeri Padang.

[7] Ikbar. Yanuar. 2014 . Metodelogi Dan Teori Hubungan Internasional. Bandung: PT Refika Aditma.

[8] Moleong,. 2010. Metodelogi Penelitian Kualitatif. Bandung : Remaja Rosdakarya.

[9] Sugiyono,. 2017. Metode Penelitian Pendidikan Pendekatan Kuantitatif, Kualitatif, dan R\&D. Bandung : AL FABETA. 